\title{
Representações de género e emigração no cinema português: o caso de $O$ Pátio das Cantigas (1942)
}

\author{
Ana Filipa Matos Maia \\ CEIS20, Universidade de Coimbra - anafilipa.m.maia@gmail.com
}

\begin{abstract}
Resumo
O cinema pode atuar no imaginário coletivo, (des)construindo imagens, estereótipos e papéis sociais reconhecidos pelas audiências. O Pátio das Cantigas é um filme português de 1942, arquétipo cinematográfico da propaganda ideológica do Estado Novo, e remete para valores tradicionais, representações estereotípicas de género e projetos de emigração, em particular para o Brasil. Este filme revela

identitárias que importa investigar no contexto do cinema português da época, mas importa também investigar como essas construções e representações estão ainda presentes na sociedade contemporânea. Assim, o objetivo deste estudo é analisar e discutir representações de género e emigração no cinema português na década de 1940, a partir de $O$ Pátio das Cantigas.
\end{abstract} construções e representações ideológicas e

Palavras-chave: género, emigração, cinema português, década de 1940.

\section{Representations of gender and emigration in Portuguese cinema: the case of The Courtyard of the Ballads (1942)}

\begin{abstract}
Cinema can have a significant impact on the collective imaginary, (de)constructing images, stereotypes and social roles recognized by the audience. O Pátio das Cantigas (The Courtyard of the Ballads) is a Portuguese film from 1942, an archetype of ideology and propaganda of the Estado Novo regime, and it addresses traditional values, representations of gender and emigration projects, particularly to Brazil. This film reveals structures and iden-

tity and ideological representations which are extremely relevant to research, in the context of the Portuguese cinema at the time, but it is also relevant to understand how these structures and representations are still present in contemporary society. Hence, the aim of this study is to analyze and discuss representations of gender and emigration in the 1940s Portuguese cinema, portrayed in O Pátio das Cantigas.
\end{abstract}

Keywords: gender, emigration, Portuguese cinema, 1940s.

(C) do(s) Autor(s) 2021. Artigo publicado online, em acesso aberto, por Interações: Sociedade e as Novas Modernidades, ISSN: 2184-3929, em https://interacoes-ismt.com, nos termos da Licença Internacional Creative Commons Attribuiçao-NãoCommercial 4.0 (https://creativecommons.org/ 
Representações de género e emigração no cinema portuguès:

o caso de $O$ Pátio das Cantigas (1942)

\section{INTRODUÇÃOO}

As comédias cinematográficas portuguesas da década de 1940 são particularmente ricas enquanto objeto de estudo, sobretudo pela sua inserção histórica e relevância sociológica. Enquanto objetos culturais e mediáticos, são profícuas em representações da ideologia dominante, difundindo, entre outras, uma visão do território rural em oposição à cidade, estereótipos de género e de experiências de emigração que aqui se propõe estudar.

Importa referir que, apesar da recorrente utilização do termo "cinema português" para nos referirmos genericamente às produções cinematográficas nacionais, percebidas como autorrepresentação de determinados discursos culturais ou ideológicos da nação, é um termo controverso e de complexa definição․ Tiago Baptista indica que se verificou um aproveitamento ideológico e político dos cinemas nacionais, em que o conceito de "cinema português" foi usado como um conceito transparente e somente geográfico (Baptista, 2010), sendo que a discussão ontológica e conceptual sobre "cinema português" persiste.

A dificuldade em definir o termo acompanha a dificuldade em encontrar estudos aprofundados que analisem a história do cinema em Portugal, sobretudo na primeira metade do século XX. A grande maioria dos escritos sobre cinema foi movida por interesses ideológicos e culturais, sem que os críticos mostrassem preocupação historiográfica ou analítica.

Segundo Baptista (2010), existem dois períodos na história do cinema em Portugal: desde a década de 1890 até à década de 1960 (no qual se insere O Pátio das Cantigas) e a fase do "cinema novo" a partir de 1960 até à atualidade. Nessa primeira fase, incluem-se sobretudo as comédias, bem aceites pelas audiências e utilizadas para intensificar questões nacionalistas, tal como O Pátio das Cantigas. A primeira fase do cinema português é a única que evidencia géneros fílmicos definidos, como os documentários, os filmes regionais e folclóricos, os filmes histórico-patrióticos e as comédias (Diogo, 2001). Contudo, as comédias eram o género mais popular, enquanto as biografias, adaptações literárias ou reconstituições de acontecimentos históricos eram ignorados pelo público (Torgal, 2011).

1 Numa obra publicada para assinalar o centenário do cinema em Portugal, João Bénard da Costa parte da afirmação polémica "o cinema português nunca existiu" (Costa, 1996, p. 9). Bénard da Costa argumenta que, ao contrário de outros países, o cinema português nunca teve um género predominante nem nunca desenvolveu um estilo próprio que conseguisse relevância internacional. 
As comédias das décadas de 1930, 1940 e inícios de 1950 têm características semelhantes e são, no conjunto da produção desta época, as formas fílmicas mais subversivas e livres, embora enquadradas num regime limitador, propagandista e num contexto de censura (Diogo, 2011). As comédias, e o cinema em geral, eram utilizadas pelo estado como ferramenta de ensino, educação moral e de propaganda, chegando a ser incluída no Decreto Lei n. 20859 de 4 de fevereiro de 1932 a citação "não virá longe o dia em que a tela substitua nas escolas o quadro negro" (Ferro, 1932 como citado em Olchówka, 2016, p. 324).

A ausência de estudos sobre o cinema português é ainda mais evidente quando se procura entender a sua articulação com as questões de género e emigração na década de 1940. É premente entender que imagens sobre as mulheres emigrantes eram veiculadas através de $O$ Pátio das Cantigas, analisar como as personagens femininas representam práticas e discursos dominantes da época e contribuir para abrir caminho na investigação acerca das questões de género e emigração representadas no cinema português da década de 1940, investigando também se e como essas imagens são atualmente veiculadas na sociedade contemporânea.

\section{METODOLOGIA(S)}

Este artigo tem como objetivo central contribuir para a estudo das representações de género e emigração veiculadas pelas comédias portuguesas da década de 1940, partindo do filme O Pátio das Cantigas enquanto objeto de estudo. Pretende-se fornecer uma base de estudos exploratórios, recolhendo literatura do tipo bibliográfico e documental. É de salientar a dificuldade em aceder a literatura que analise aprofundadamente os filmes desta década em Portugal, particularmente com enfoque em questões de género e emigração.

Foi na década de 1970 que surgiram novas linhas de investigação, com maior enfoque na importância da historiografia para a análise dos filmes e seus contextos históricos, culturais e socioeconómicos. O historiador Marc Ferro foi fundamental para a reflexão sobre a relação entre o cinema e as circunstâncias históricas da produção cinematográfica, defendendo os filmes como documentos históricos que vale a pena investigar. Assim, o cinema das primeiras décadas do século XX poderá ser mais do que uma distração comercial, limitado pelos seus cânones estéticos (Olchówka, 2016), e poderá ser considerado instrumento de estudo para diferentes áreas científi- 
Representações de género e emigração no cinema portuguès: o caso de $O$ Pátio das Cantigas (1942)

cas. Também na década de 1970, o advento dos estudos feministas e da teoria fílmica feminista permitiu novas abordagens, metodologias e maior pluralidade de perspetivas de investigação. Essa década representa uma mudança de paradigma na crítica cinematográfica, pautada sobretudo pela inclusão dos estudos culturais e feministas na investigação académica. Para Teresa de Lauretis, o feminismo não só criou novas estratégias e novos textos, mas "concebeu um novo sujeito social, as mulheres: como oradoras, escritoras, leitoras, espectadoras, consumidoras e produtoras de modelos culturais" (Lauretis, 1985, p. 163). Para Ana Catarina Pereira, em "A Mulher Cineasta", estudar e analisar cinema seguindo um ponto de vista feminista implica "uma alteração de foco que se distancia da análise puramente textual e se aproxima das estruturas de identificação e prazeres visuais provocados", estruturas que são centradas na "relação espectador-ecrã", relação esta que determina a constituição do sujeito feminino (Pereira, 2016, p. 129), procurando torná-lo visível.

No entanto, os estudos de género no cinema português revelam-se ainda escassos, tanto a nível nacional como internacional, sobretudo no que diz respeito a comédias da década de 1940. Ana Catarina Pereira aponta para "uma quase inexistência de bibliografia especializada em língua portuguesa" e para um desconhecimento da temática dos estudos fílmicos feministas e de pesquisadores/as feministas por parte dos/as alunos/as que estudam cinema em contexto académico (Pereira, 2016, p.17). Nesse sentido, a dificuldade em aceder a bibliografia especializada levou à necessidade de incluir literatura transdisciplinar que cruzasse os estudos sobre os media, e em particular o cinema, os estudos feministas e os estudos sobre a emigração portuguesa, no contexto histórico do Estado Novo².

Apesar de $O$ Pátio das Cantigas ser rico em informação para diferentes linhas de investigação, pretende-se aqui analisar representações de género e emigração presentes no filme enquanto objeto cultural e mediático. Para tal, revelou-se crucial recorrer à análise do conteúdo e do discurso, procurando recolher e investigar material simbólico, com enfoque em momentos da narrativa, falas das personagens, imagens e cenários icónicos.

2 Regime político ditatorial que ocorreu de 1933 a 1974, em Portugal, e cuja figura central foi António de Oliveira Salazar. 


\section{AS COMÉDIAS PORTUGUESAS DA DÉCADA DE 1940}

Convencionalmente, a expressão "comédias à portuguesa" refere-se à produção do período do Estado Novo vocacionada para o entretenimento e, também, para a educação das massas. A maior parte das comédias desta época inclui as ideologias do regime, veiculadas através de temáticas em que se destaca "a cidade, onde sobressaem os valores, os pequenos dramas e as pequenas comédias do povo, ou o campo, sempre o lugar de encontro das verdadeiras virtudes" e a moral, com "a pobreza honesta, a conciliação de classes, os valores patrióticos, o premiar das virtudes e o castigo dos vícios" (Torgal, 1996, p. 310). Estas temáticas estão presentes nas comédias das décadas de 1930, 1940 e ainda inícios de 1950.

Apesar de existirem produções privadas, as verbas eram muitas vezes colmatadas com financiamento estatal, cuja influência levava, uma vez mais, a constrangimentos estético-ideológicos (Diogo, 2011). António Ferro, diretor do Secretariado de Propaganda Nacional e grande "doutrinador da política cultural do Estado Novo" de 1936 a 1946 (Diogo, 2001, p. 306) protagoniza um forte controlo da produção cinematográfica nacional e internacional, a quem interessava criar filmes com rentabilidade. Vasco Diogo acrescenta que a censura atuava também nas obras fílmicas que chegavam a Portugal, alterando traduções nos diálogos e selecionando ou interditando material de acordo com o seu conteúdo.

As produções de cinema nacionais aliavam-se a outras formas de cultura popular, como o teatro, a música e a rádio, aproximando-se do seu público-alvo, segundo Diogo, "maioritariamente audiências com um nível de instrução baixo ou analfabetas", cativado por estratégias de "promoção dos filmes dentro de meios da cultura de massas, sobretudo revistas e a rádio" (Diogo, 2001, p. 303). As histórias destes filmes não têm "grandes «ambições artísticas» de criação individual" mas procuram aproximar-se das audiências através de estratégias de familiarização ${ }^{3}$ com os espetadores e espetadoras.

O Pátio das Cantigas não foi o único filme a ser utilizado com objetivos de propaganda nacional. António Ribeiro, que também produziu O Pátio das Cantigas, foi um dos cineastas portugueses que mais utilizou "esta campanha de propaganda através do cinema e o mais bem preparado tecnicamente" (Torgal, 1996, p. 298). Nas palavras

3 Diogo destaca que uma das estratégias de familiarização terá sido a voz off de António Lopes Ribeiro, com o objetivo de transportar os espetadores e espetadoras para dentro da ficção, resumindo a intriga, tipificando personagens e explicando a ação. Esta estratégia continuou a ser utilizada, nomeadamente em televisão, até aos dias de hoje (Diogo, 2001). 
Representações de género e emigração no cinema portuguès:

o caso de $O$ Pátio das Cantigas (1942)

de Henrique Alves da Costa, "sempre presente e atento, a António Lopes Ribeiro não escapam as propícias circunstâncias que, devido à guerra mundial, se apresentam para a defesa comercial do filme português" (Costa, 1978, p. 81). Para Patrícia Ferraz Matos, e pensando o cinema como um "agente da história", os filmes ideológicos ou de propaganda são uma "fonte importante para fazer história". A autora acrescenta que a realização de filmes durante o Estado Novo parece estar relacionada com a história nacional e com representações com "uma carga ideológica muito forte" (Ferraz Matos, 2006, p. 96).

Como indica Paulo Cunha (2016), apesar de as décadas de 1930-1940 serem uma "época dourada do cinema" ao nível da sua popularidade, são das menos estudadas pela historiografia. Mais, não existem dados de bilheteira anteriores a 1976, o que torna complexo analisar a receção por parte do público. Para tal, o autor propõe analisar o tempo de permanência em sala: $O$ Pátio das Cantigas esteve apenas quatro semanas em exibição. Apesar deste curto tempo de exibição, Cunha sugere que a razão pela qual esta e outras comédias se terem popularizado no imaginário público português tem que ver com o facto de a televisão ter, nas décadas de 1960 e 1970, emitido de forma exaustiva e regular determinados filmes, de determinados realizadores, como $O$ Pátio das Cantigas. Tal levou à consolidação de um cânone de cinema, popularizando personagens e, inclusive, expressões reconhecidas e reproduzidas pelas massas, da qual é arquétipo “Ó Evaristo, tens cá disto?". Para Costa, O Pátio das Cantigas era visto como uma comédia ligeira e esquemática, "com um certo sentido de humor caricatural", inserindo-a no "cinema de bairro, em tom cor de rosa", com uma "sociedade de gente simples, sã, alegre e trabalhadora, onde as únicas nuvens eram as inevitáveis paixões «humanas»" (Costa, 1978, p. 81).

Neste filme assistimos também a múltiplos momentos simbólicos que remetem para António de Oliveira Salazar e o Estado Novo. A construção das personagens, os diálogos, as suas ações e respetivas recompensas e castigos morais e a própria mise-en-scène fazem parte de um complexo esquema ideológico que pretendia criar e difundir determinadas imagens culturais e sociais.

\section{O PÁTIO DAS CANTIGAS (1942)}

O Pátio das Cantigas é uma comédia portuguesa de 1942, realizada por Francisco Ribeiro/Ribeirinho e produzida pelo irmão António Lopes Ribeiro. Está contextua- 
lizada historicamente no Estado Novo e a narrativa acontece aquando das festas dos santos populares, tendo como cenário um bairro lisboeta. O elenco do filme incluía António Silva (Evaristo), António Vilar (Carlos Bonito), Carlos Otero (Alfredo), Graça Maria (Suzana), Maria da Graça (Maria da Graça), Maria das Neves (senhora Rosa), Maria Paula (Amália), Narciso (Francisco Ribeiro), Vasco Santana (Narciso), entre outros/as artistas.

Nos primeiros minutos, temos acesso a imagens de Lisboa, representadas pelos edifícios tradicionais do pátio. O narrador, ou voz off, apresenta as personagens e descreve-as sucintamente, por vezes de forma pejorativa, condicionando, desde logo, a visão do/a espetador/a. O narrador surge somente no início, introduz as personagens, indica os seus nomes e como estão relacionadas entre si, e ainda acrescenta, brevemente, características e traços de personalidade. Tal fará com que os/as espetadores/as sejam influenciados/as pelo narrador, adquirindo expetativas e opiniões acerca das personagens antes de iniciar a narrativa. Com a apresentação das figuras centrais, compreendemos desde logo que esta se irá focar nas redes de relações familiares, laborais e românticas entre pessoas que vivem num pátio lisboeta e que serão elas as protagonistas desta comédia.

Para além das relações entre personagens, compreendemos também que existem mensagens não tão subtis, no contexto da propaganda salazarista, ao nível de imagens, objetos, valores morais, recompensas e castigos morais que as personagens vão recebendo, e assistimos a múltiplos momentos simbólicos que remetem para Salazar e o Estado Novo. Um exemplo paradigmático é a cena em que, após fortes desacatos entre os/as populares num arraial, a personagem de Vasco Santana, Narciso, guia um grupo de crianças assustadas, leva-as para um barco de diversão e diz "podem estar sossegadinhos que aqui não lhes acontece mal nenhum". A câmara foca então o nome do barco: "Salazar". Temos aqui o cinema ao serviço da propaganda estatal, reforçando a presença de Salazar e a visão de Salazar como protetor da nação.

Pouco após um convívio, e aquando do regresso provisório de Maria da Graça, a personagem emigrada no Brasil, o Senhor Heitor chega perturbado e explica aos restantes que foi roubado e agredido, que o ladrão terá roubado 15 contos e fugido. $\mathrm{Na}$ cena seguinte, vemos Carlos a contar a Amália que já tem o dinheiro de que precisavam - pairando imediatamente a suspeita de que poderá ter sido Carlos o criminoso. Com o fado como banda sonora, o frágil avô Heitor está no seu leito e Suzana em lágrimas na mesa da cozinha; a imagem e a música aliam-se para intensificar o sentimento de tristeza e desilusão da cena. Apesar de não assistirmos ao roubo, sabe- 
Representações de género e emigração no cinema portuguès: o caso de $O$ Pátio das Cantigas (1942)

mos que este aconteceu numa rua de Lisboa fora do pátio, sublinhando os perigos do exterior. É no regresso ao pátio, àquele pequeno espaço, que Heitor recebe o apoio e solidariedade das netas e da vizinhança. Embora se situe num bairro da capital do país, o espaço restrito do pátio, de algumas ruas adjacentes e dos pequenos e mais intimistas espaços interiores das casas (os seus quartos, salas e varandas), faz com que os/as espetadores/as pensem que estão a observar uma pequena aldeia, onde os afetos e os dramas pessoais são conhecidos e partilhados por todos/as os/as habitantes. O realizador procurou mostrar uma perspetiva de Lisboa popular, pré-moderna e com valores tradicionais, cujos/as residentes parecem estar distanciados/as da restante população urbana lisboeta. As ruas aqui são sempre espaços vazios, onde não passa ninguém para além das personagens centrais do filme e dos locais onde trabalham (e.g. a drogaria, o mercado e a leitaria). Parece assim que o realizador, à semelhança de outros filmes da época, procurou associar a ruralidade ao sentimento de segurança, associando o espaço citadino/urbano à violência e ao perigo.

Após esse trágico momento, o enredo avança para a dinâmica amorosa de Narciso e Rosa. Rosa consente casar com Narciso na condição de este deixar de beber álcool e se recompor, numa espécie de recompensa moral. No final do filme, descobrimos que Carlos foi injustamente preso, acusado do roubo ao senhor Heitor. Na verdade, o dinheiro que Carlos tinha consigo terá vindo de Evaristo, em jeito de empréstimo, para que Carlos e Celeste pudessem ir em tournée para o Brasil (compreendemos que Carlos vai convidando, de forma interesseira, diferentes personagens femininas para fazer dupla musical consigo, de forma a cumprir o seu objetivo migratório). O verdadeiro criminoso é, entretanto, apanhado pela polícia. O agente indica ainda "a polícia não é tão má como dizem", numa clara tentativa de promover a imagem da polícia através do filme.

A música acompanha a narrativa, servindo de intensificador ou apaziguador de emoções e impondo ritmo e tonalidade trágica ou cómica. Para Claudia Gorbman (1987), a música tem um papel determinante na leitura de um filme - aumenta a suscetibilidade para a sugestão, induzindo e guiando a atenção do/a espetador/a, incluindo ou excluindo elementos. Em O Pátio das Cantigas, existem dois géneros musicais utilizados: o fado e o samba. O fado é utilizado por várias personagens, em contextos de tristeza, desilusão e angústia, geralmente provocada pelo fracasso amoroso. Por outro lado, o samba é sobretudo utilizado em ocasiões de alegria, novas oportunidades e otimismo, dançado e cantado por Maria da Graça. 
No final, as ruas surgem, pela primeira vez, como lugares de alegria, harmonia e proximidade, ao invés de espaços de solidão, vazio ou perigo anteriormente retratados, onde os/as protagonistas agora se aproximam do resto da população residente. Praticamente todas as personagens centrais parecem encontrar par romântico no final do filme, nomeadamente Rufino e Maria da Graça. Rufino decide mudar o nome da leitaria, de "Estrela de Alva" para "Estrela Luso-brasileira". O filme encerra alegremente, com toda a gente a cantar e a dançar nas marchas populares no pátio (das cantigas).

\section{REPRESENTAÇÕES DE GÉNERO E EMIGRAÇÃO}

O cinema, enquanto media, "constrói e representa quadros de realidade através da utilização de códigos, convenções e ideologias conhecidos e reconhecidos socialmente" (Santos, 2002). Enquadradas na ideologia do Estado Novo, as comédias portuguesas e, em especial, O Pátio das Cantigas, apresentam personagens com características e comportamentos valorizados ou rejeitados segundo a moral salazarista. Nesse contexto, selecionaram-se duas áreas críticas de investigação, género e emigração.

Em O Pátio das Cantigas, à semelhança da larga maioria das produções fílmicas, encontramos imagens estereotipadas de género reconhecidas pelas audiências, com as personagens masculinas a assumir papéis de protagonistas, enquanto que as mulheres representam papéis secundarizados sempre em relação aos homens - serão as donas de casa, as suas irmãs, as suas esposas ou interesse romântico. Segundo Laura Mulvey, no seu ensaio "Visual Pleasure and Narrative Cinema", o cinema apresenta um olhar predominantemente masculino, com mecanismos que dividem os homens em seres ativos e as mulheres em seres passivos. As personagens femininas servem a narrativa para satisfazer os desejos dos homens ou a contemplação erótica, exercida "on either side of the screen", ou seja, exercida dentro e fora do ecrã, tanto por parte das personagens masculinas como dos espetadores (Mulvey, 1975).

Um dos protagonistas masculinos do filme, o galã, é Carlos Bonito (interpretado por António Vilar). Carlos engendra estratégias para conquistar as raparigas do bairro, em constante sedução, mas as suas atitudes de sedução são vistas como "um estigma alegre que não é senão o traço característico do mulherengo", visto como algo "natural, homólogo à traquinice das crianças" (Marques, 2016, p. 11). Por outro lado,

a leitura que se tem da personagem Amália é depreciativa. A personagem feminina é, 
Representações de género e emigração no cinema portuguès:

o caso de $O$ Pátio das Cantigas (1942)

desde logo, apresentada pelo narrador nos primeiros minutos do filme como "bonita, mas leviana”. Posteriormente, Amália acaba por confessar a Alfredo, por quem está apaixonada, que já namorou o irmão deste, Carlos Bonito, sem ter gostado dele, tal como fez com outros homens. Segundo esta leitura, esta confissão projeta a antítese do que as raparigas solteiras deveriam aspirar.

Refletindo sobre as publicações da imprensa na década de 1940, Isabel Freire escreve que os artigos pretendem "ajudar as raparigas solteiras e as mulheres casadas a compreender e interiorizar o papel de guardiãs da conjugalidade”, das quais depende "o sucesso e felicidade da vida a dois" (Feire, 2013, p. 58). Alfredo faz também referência à felicidade do matrimónio ao idealizar Suzana (irmã de Amália) "Estou a vê-la, muito bonita, muito alegre, numa casita [...] havemos de lá viver muito felizes sem pensar em nada [...] Quando eu vier do trabalho hei-de vê-la à minha espera”. Estas referências remetem para a projeção passiva da mulher, vista como cuidadora do lar. Assim, Amália e Suzana são retratadas com níveis de moralidade opostos, não só pela forma como atuam com os seus pares românticos, mas também, como mencionado futuramente, nas suas relações com o dinheiro e ambições de futuro.

Em geral, a vida de casal não é retratada no filme, apenas temos acesso à representação da conquista e do namoro inicial, muitas vezes de forma ligeira e cómica. Não existe a problematização da sexualidade, do divórcio ou de qualquer dificuldade matrimonial. Como refere Bruno Marques, o matrimónio era uma instituição demasiado séria para ser problematizada nas produções cinematográficas, não surge como tema de discussão ou intriga (Marques, 2016). O casamento é visto como o derradeiro objetivo e podemos observar que vários pares românticos se estabelecem no final do filme. Para Susana Santos, "o final das narrativas assenta no restabelecimento da ordem inicial, em que o peso da instituição e os valores morais das mulheres casadas ganham a batalha" (Santos, 2002, p. 142). No caso de O Pátio das Cantigas, o filme encerra com alguns dos vários pares de apaixonados: Carlos e Suzana aproximam-se para se beijaram, mas o plano é cortado antes de tal acontecer; João Magrinho e Celeste olham o par anterior e, posteriormente, João tenta beijar Celeste, que lhe dá uma estalada; e Alfredo e Amália também se aproximam e o plano é cortado, novamente, antes de o beijo se concretizar. De acordo com Vasco Diogo, "a visibilidade do beijo é-nos dada somente de forma indireta através do olhar de João Magrinho e Celeste, provocando a última uma inversão da série potenciadora de um efeito cómico. Ao mesmo tempo legitima-se uma moral puritana" (Diogo, 2001, p. 310), uma moral em que, à época, o beijo em público, na rua, era punível por lei. 
Para Susana Santos, os comportamentos demonizados e sancionados estão relacionados com as posições sociais e com os valores morais e sexuais das personagens, em que se valoriza o recato e a submissão, sobretudo das personagens femininas (Santos, 2002), o que corresponderia a valores morais da sociedade da época. Para além de Amália, descrita como "namoradeira" e "leviana" ao longo do filme, também Maria da Graça surge como menos recatada, uma personagem que se veste e fala de forma diferente das restantes mulheres do pátio. Maria da Graça é duplamente relevante para este estudo, não só por ser uma personagem feminina com destaque na narrativa, mas também por ser representativa do projeto de emigração para o Brasil.

Neste período, há outras produções cinematográficas que abordam a emigração da população portuguesa (e.g. O Grande Elias, de 1950; Sonhar é Fácil, de 1951), com especial enfoque para o continente americano (Brasil e Argentina, respetivamente). É de destacar o Brasil, pois tal era, à época, um dos principais países de acolhimento. Os dados e a informação estatística disponível indicam que "do total de partidas verificadas até 1960 mais de 80\% dirigiam-se para as Américas, sendo o fluxo migratório para o Brasil sempre o mais volumoso" (Baganha, 1994, p. 960), numa referência ao ciclo transatlântico. Segundo Maria Ioannis Baganha, conhece-se com algum rigor o volume de saídas, as principais regiões de origem e destinos migratórios e também se identifica um perfil de emigrante típico até aos anos 30 que emigraria para os Estados Unidos da América: homem, entre 16 e 29 anos de idade, solteiro e sem qualificações específicas. Todavia, não existe o mesmo rigor na compreensão da composição sociodemográfica do fluxo migratório para o Brasil dessa época (Baganha, 1994) e menos dados há ainda sobre os perfis demográficos das mulheres migrantes.

Os censos demográficos 1940-1950 realizados pelo Instituto Brasileiro de Geografia e Estatística (IBGE) mostram "que os estrangeiros do sexo masculino mantiveram uma maior participação ao longo de todo o período, confirmando a ideia da primazia masculina nesse processo" (Melo, 2014, p. 437). Do total de estrangeiros/as no Brasil, $27,9 \%$ eram homens portugueses e 22,3\% eram mulheres portuguesas (Melo, 2014, p. 440) e, especificamente em 1940, a população portuguesa residente no Brasil era composta por 221195 homens (62\%) e 136979 mulheres (38\%). Apesar de ter havido um ligeiro aumento da presença feminina no projeto de emigração para o Brasil, este foi sempre predominantemente masculino (Melo, 2014).

Para além destes números e dados estatísticos, ao longo do processo também se configuraram marcas socio-identitárias, construíram-se imagens estereotipadas do indivíduo português fixado no Brasil, desenvolvidas tanto pela comunidade do país 
Representações de género e emigração no cinema português:

o caso de $O$ Pátio das Cantigas (1942)

de acolhimento, como da comunidade do país de origem. Fátima Velez de Castro remete para Norberto Santos (Santos 2005, como citado em Velez de Castro, 2013), indicando que, tendo como base a análise de obras literárias, existe uma caricatura do indivíduo português que emigra para o Brasil. Para essas construções caricaturais contribuiu também o cinema português, sobretudo com as comédias da época.

Autoras como Isabel Ferin Cunha e Clara Almeida Santos têm estudado os media e a temática das mulheres, nomeadamente na análise das mulheres imigrantes na imprensa escrita e na televisão portuguesas. Cunha explora imagens da mulher brasileira na televisão contemporânea, em particular através das telenovelas, e como esta influencia o imaginário coletivo português, e afirma que a "intertextualidade se cria entre as imagens e representações do Brasil e dos brasileiros - particularmente das mulheres brasileiras - presentes, todos os dias, nas telenovelas e peças dos jornais televisivos" (Cunha, 2005, p. 535). Para Cunha, a "sistemática atribuição de determinadas representações" e de características, comportamentos e atitudes das mulheres brasileiras veio promover estereótipos (Cunha, 2005, p. 535), sendo que alguns desses estereótipos estavam presentes nos filmes da década de 40 e continuam a ser encontrados nos media e na sociedade portuguesa atual. Clara Almeida Santos verifica a "construção de um estereótipo assente na imagem da mulher exótica, orientada para práticas sexuais a troco de dinheiro" (Santos, 2005, p. 51). Esta construção é também difundida pela imprensa escrita, que apela ao imaginário coletivo, e vende imagens de sexualidade e sedução da "mulher brasileira", estigmas e estereótipos que tendem a ter uma dimensão negativa, redutora e de desvalorização social e individual e que, segundo Santos, foram construídos desde os tempos coloniais e permanecem na atualidade.

Em O Pátio das Cantigas, Maria da Graça, filha de Rosa, representa a migrante portuguesa no Brasil que adquire características estereotipadas das mulheres brasileiras. Mara da Graça trabalha na rádio no Brasil e regressou ao pátio para visitar a mãe, durante dois meses. É bem recebida pelos/as outros/as habitantes do pátio, visivelmente encantadas pelas roupas que ostenta, e há múltiplas referências a jóias, carros, casacos e dinheiro conseguidos pela personagem. Para além disso, várias personagens, como Amália e Carlos, ambicionam emigrar para o Brasil à procura de uma vida melhor. Maria da Graça é representada como uma mulher independente, rica, animada e com jeitos de vestir e agir bastante diferentes das mulheres do pátio. No entanto, acentua-se que emigrar é uma solução difícil de concretizar e que quem 
emigrou ambiciona regressar e ter uma vida humilde, tal como Maria da Graça, que afirma preferir regressar ao pátio e ter uma leitaria e deixar o Brasil.

É na segunda metade do filme que assistimos à maior parte das referências à emigração para o Brasil. Um dos primeiros momentos a introduzir a temática da migração surge através de Carlos Bonito. Carlos pergunta a Rufino "Sabes por acaso se há algum barco a sair para o Brasil?”. Rufino ignora-o, estando distraído, entre gargalhadas, a ouvir a rádio. Pouco depois encontra-se com Amália e convida-a a "dar um passeio até ao Brasil". Uma vez que Carlos toca guitarra e Amália canta, pensou em formar um duo musical e emigrar para o Brasil, como a filha da senhora Rosa, que "saiu daqui em pequenina e agora está cheia de dinheiro a cantar na rádio". Inicialmente, Amália mostra-se surpresa com a proposta, mas, após o comentário acerca da riqueza da emigrante, fita o horizonte com olhar sonhador, recordando uma fotografia da filha de Rosa vestindo "casaco de peles, cheia de jóias e ao pé de um automóvel". No entanto, rapidamente desanima, lembrando que não tem "dinheiro para as passagens e para tudo o que é preciso". Confiante, Carlos responde "se nós quisermos, o dinheiro arranja-se".

De seguida, observamos as duas irmãs, Suzana e Amália, a discutir o dinheiro guardado pela família. Amália afirma que não pretende utilizar a parte destinada à irmã, mas que tem direito a utilizar a sua, com o objetivo de cumprir o desejo de migrar para o Brasil com Carlos. Também Carlos e o seu irmão Alfredo têm uma conversa semelhante. Alfredo aconselha prudência ao irmão, dizendo que "a herança é pequenina mas um dia pode vir a servir no caso de uma doença ou de uma infelicidade". Apesar de nenhuma das personagens conseguir convencer o respetivo irmão/irmã a receber a sua parte do dinheiro, Carlos mostra-se decidido a conseguir cumprir o objetivo. Neste segmento é salientada a valorização moral do indivíduo humilde e simples, que poupa a pensar no futuro e aceita a sua condição socioeconómica (através de Suzana e Alfredo), enquanto se evidencia a crítica às personagens ambiciosas que procuram ascensão social (Amália e Carlos), em particular na construção do ideal de emigração para o Brasil e o sucesso material.

No contexto de emigração, há outros momentos relevantes que nos levam a refletir acerca da emigração para o Brasil. Vejamos agora o caso de Evaristo, que diz à filha: "Deixa cá espreitar estes fox trot brasileiros que o Carlos me aconselhou", referindo-se a "Camisa Amarela", ironizando que era uma música comemorativa do vencedor da volta ao Brasil em bicicleta. Celeste pergunta quem foi esse vencedor, ao que Evaristo 
Representações de género e emigração no cinema portuguès:

o caso de $O$ Pátio das Cantigas (1942)

responde "foi Pedro Álvares Cabral", numa clara referência à época dos descobrimentos. Imediatamente, e assim que soa a música, vemos a filha de Rosa, Maria da Graça, a chegar de carro e posteriormente a cantar e a dançar um samba brasileiro, alegremente recebida pelas pessoas que estão no pátio, nomeadamente os homens, que se mostram encantados por ela.

A roupa com que surge em cena e o jeito informal com que trata as restantes pessoas transmite a ideia de que o "destino brasileiro permite uma liberdade de costumes às mulheres, nem sempre bem visto em território luso" (Velez de Castro, 2013, p. 882). Contudo, a função de Maria da Graça na narrativa não é promover a imagem da mulher emigrante emancipada. Maria da Graça mostra que ainda se recorda bem do pátio e das pessoas, inclusive dos seus nomes e profissões, relembrando a mítica frase “Oh Evaristo, tens cá disto?", para regozijo das outras personagens. Quando se reencontra com a mãe, Maria da Graça indica poder ficar por dois meses em Lisboa, mas que terá de voltar para não perder o seu contrato de trabalho com a rádio. Temos aqui o regresso ao país de origem de curta duração, sob a forma de férias. No entanto, apesar dessa indicação do regresso após dois meses, para Velez de Castro, o facto de Maria da Graça recordar as características identitárias das outras personagens, como se nunca tivesse saído do pátio, representa "um processo mais ou menos assumido de retorno à pátria” (Velez de Castro, 2013, p. 881).

Nos momentos finais do filme, Rufino, filho de Narciso, pediu autorização a Maria da Graça para que o pai pudesse casar com Rosa. Tal como indicado por Velez de Castro (2013), existe a ideia de que o/a emigrante que retorna do Brasil tem capacidade de resolver problemas materiais e imateriais, mostrando o seu poder e autonomia, bem como a sua evolução em termos profissionais, económicos e pessoais. Aqui, a sua bênção mostra-se importante para as restantes pessoas. Para além disso, Rufino mostra-se também interessado em Maria da Graça, que rapidamente se apresenta disponível para ficar definitivamente em Portugal se alguém lhe oferecer "uma leitaria", o que remete para o objetivo de regressar às origens humildes como o destino ideal/final do seu projeto migratório. Rufino fica radiante e aceita a ideia, dizendo-lhe "I love you", ao que Maria da Graça responde "deixa-te de estrangeiradas e beija-me em português". Rufino dança ao som da canção de Maria da Graça, um tema mais feliz e com ritmos brasileiros, que privilegia a língua portuguesa. 


\section{CONSIDERAÇÕES FINAIS}

Esta análise focou-se, especialmente, nas personagens femininas Amália, Suzana e Maria da Graça, nas suas dicotomias e nível de moralidade, utilizadas não só para entreter, mas, sobretudo, para educar as massas para os valores patriarcais da época. Estas figuras são relevantes não só para compreendermos quais as representações das mulheres à época, ensinando quais os comportamentos e aspirações que deveriam seguir, mas também em termos comparativos com as demais personagens masculinas, dominantes no filme. Para Mulvey, a mulher está ligada a uma ordem simbólica, a uma cultura patriarcal, carrega significado, mas não o produz, a mulher existe como significante do outro masculino (Mulvey, 1975). Assim, assistimos à passividade das personagens femininas e as suas relações de dependência narrativa e moral às personagens masculinas. Esta contemplação é vista como forma de exercer poder, em que "os homens atuam e as mulheres aparecerem", as mulheres observam-se a serem olhadas pelos homens, o que determina muitas relações entre homens e mulheres, mas também a relação das mulheres consigo mesmas (Berger, 1972, p. 47 como citado em Butler, 2002, p. 4).

Mesmo quando temos personagens mais emancipadas e independentes, como Maria da Graça, o/a espetador/a acompanha a vontade desta em abandonar as suas conquistas em terras brasileiras. A atitude saudosista de Maria da Graça ajuda a representar a pessoa migrante que deseja regressar ao seu país de origem e levar uma vida humilde, apesar de todas as liberdades e riquezas materiais que terá conseguido no Brasil. Podemos argumentar que Maria da Graça serve um propósito de propaganda do Estado Novo, através de construções espácio-identitárias divulgadas pelo cinema. Fátima Velez de Castro indica que, em algumas comédias da época, parece existir uma representação dicotómica entre "a candura/inocência nacional" e "a lascívia tropical assente numa sociedade mais aberta e liberal face ao papel da mulher" (Velez de Castro, 2013, p. 882) Tal é representado por Maria da Graça, tanto pelas referências à sua forma de vestir, de falar com as restantes personagens, e pela intenção de abandonar a sua carreira bem-sucedida na rádio, no Brasil, para casar, ficar no "pátio" português e trabalhar numa leitaria, regressando às origens - uma imagem de vida rural e simples, promovida, aliás, em todo o filme, em detrimento da imagem da mulher solteira, materialista e dedicada à profissão primeiramente apresentada.

Verifica-se ainda que alguns estereótipos da mulher brasileira e da emigrante em território brasileiro difundidos nesta década, representados pela caricatura da 
Representações de género e emigração no cinema português:

o caso de $O$ Pátio das Cantigas (1942)

mulher exótica e sexualizada, são ainda sistematicamente veiculadas pelos media atuais. Refletindo sobre o estudo de Smiers (2006) acerca de diversidade cultural e globalização, Rosa Cabecinhas, Isabel Macedo e Renné França indicam que se observa atualmente "um forte incentivo a obras audiovisuais que promovam a diversidade cultural, no entanto, persistem estereótipos nas imagens veiculadas pelos produtos fílmicos sobre as populações migrantes" (Cabecinhas, Macedo, \& França, 2019, p.5).

Para além das representações de género e referências a projetos migratórios, o filme inclui múltiplas referências de propaganda à ideologia do Estado Novo. Citando Carla Ribeiro, durante as décadas de 1930 e 40 o cinema foi dominado pelas "funções de veículo de cultura popular como a entendem os responsáveis: divertir, formar politicamente" e interessava explorar "o filão nacionalista" (Ribeiro, 2011, p. 214). Estas referências são, como vimos, mais ou menos subtis, e são percetíveis através da construção das personagens, das suas falas, atitudes e experiências de vida, bem como da constante valorização das gentes do campo e da agricultura, em contraste com a cidade (geralmente Lisboa) e as suas associações a violência, perigo e imoralidade. As audiências identificavam-se facilmente com as personagens e as temáticas, já que grande parte da população vivia em zonas rurais, e o cinema chegava a um vasto número de pessoas rapidamente, o que se mostrou terreno fértil para a utilização do cinema como instrumento de criação e projeção de uma determinada imagem territorial.

O Pátio das Cantigas não apresenta personagens femininas com marcadores de identidade complexos e individualizados, enfatizando, ao invés, o discurso patriarcal da época. Tal como esta, as produções cinematográficas produzidas na década de 1940 refletem discursos e ideologias dominantes. Também os realizadores, artistas e outros profissionais estavam limitados política e ideologicamente. Através de atos legislativos e de controlo, não transmitiam histórias ou visões individuais ou subjetivas, mas expressavam ideais, condenavam rebeldes e instruíam as novas gerações (Torgal, 2011). Carla Ribeiro enumera alguns dos constrangimentos com que se debatia a indústria cinematográfica portuguesa, apesar dos esforços do governo. Ribeiro menciona a dificuldade da eletrificação do país, a falta de meios técnicos, os impostos de exibição e os elevados custos de produção. Acrescenta ainda que muitos cinemas funcionavam apenas uma ou duas vezes por semana, que os mercados de exportação (e.g. Brasil) estavam fechados à produção portuguesa e que o cinema estrangeiro começava a dominar o mercado cinematográfico (Ribeiro, 2011, p. 29).

A década de 1950 mostrou que também as comédias estavam a perder o interesse do público. O ano de 1955 é icónico para a história do cinema português e foi 
considerado um "ano zero", já que não estreou qualquer filme de longa-metragem de produção nacional ${ }^{4}$. (Cunha, 2016). No entanto, este e outros filmes não foram esquecidos pelos media e regressariam regularmente aos ecrãs, desta vez através da televisão, nas décadas seguintes, contribuindo para a sua consolidação no imaginário nacional.

Para Isabel Macedo, as narrativas que se constroem em torno do passado têm impacto na memória coletiva e no imaginário da identidade nacional, sendo fundamental desconstruir e refletir sobre as narrativas hegemónicas do passado para também compreender como ecoam no presente. Macedo cita Erll e Rigney (2009) e refere "os processos mediáticos através dos quais as memórias chegam à esfera pública e se tornam coletivas", sendo que a memória social deverá "ser estudada no cruzamento de ambos os processos sociais e mediáticos" (Macedo, 2016, p. 275). Importa não só examinar o potencial artístico e de entretenimento do cinema, mas também abrir caminho para uma abordagem multidimensional e interdisciplinar, que promova diálogo, por exemplo, com os estudos culturais, com a sociologia, com a linguística e com a história.

A análise a este filme é apenas uma análise possível e parcial, pois existem sempre outras perspetivas e leituras a fazer. No entanto, pretende ter servido como base exploratória para posteriores reflexões. Recorda-se que o enfoque na análise do filme se concentrou nas representações de género e emigração, refletindo ainda sobre a construção de imagens territoriais e a valorização da ruralidade e de valores tradicionais da época. Esta longa-metragem é rica em informação acerca do projeto migratório e utiliza estratégicas para o representar muito semelhantes a outras da época (tal como a inclusão de personagens femininas, caricaturadas de forma positiva, que ajudam as suas famílias em momentos de crise e que mostram vontade de regressar ao país de origem para viver uma vida humilde). Recordamos que os/as principais protagonistas estão interligados/as de alguma forma, através de relações amorosas, familiares, laborais ou simplesmente de vizinhança. Destacamos algumas das figuras femininas, como as irmãs Amália e Suzana, que representam mulheres com personalidades e níveis de moralidade opostas, e Maria da Graça, a emigrante no Brasil.

4 Embora tivessem sido criados dezenas de filmes de curta-metragem nesse ano, foram desvalorizados e desconsiderados pelos estudiosos e pela crítica. É considerado "ano zero" pela ausência de produção de longas-metragens.

5 Cf Erll, A. \& Rigney, A. (2009). "Introduction: Cultural memory and its dynamics”. In A. Erll \& A. Rigney (eds.) Mediation, remediation, and the Dynamics of cultural memory, pp.1-14. Berlin, New York: Walter de Gruyter. 
Representações de género e emigração no cinema português:

o caso de $O$ Pátio das Cantigas (1942)

Este pátio funcionará como arquétipo de um pequeno espaço onde todas as pessoas se conhecem, partilham alegrias, ambições, amores e desamores, tragédias e desilusões. Ali convivem e se relacionam personagens que ficaram na história do cinema português.

\section{REFERÊNCIAS}

Baganha, M. I. (1994). As correntes emigratórias portuguesas no século XX e o seu impacto na economia nacional. Análise Social, vol.XXIX, 959-980.

Baptista, T. (2010). Nationally Correct: The Invention of Portuguese Cinema. Portuguese Cultural Studies, 3, 3-18.

Butler, A. (2002). Women's cinema. The contested screen. London:Wallflower Press.

Cabecinhas, R., Macedo, I., \& França, R. (2019). Cinema, migrações e diversidade cultural: nota introdutória. Revista Lusófona De Estudos Culturais, 6(1), 5-11|13. https://doi.org/10.21814/rlec.380

Costa, J. B. (1996). O Cinema Português nunca existiu. Lisboa: CTT.

Costa, H. A. (1978). Breve história do cinema português (1896-1962). Lisboa: Instituto da Cultura Portuguesa.

Cunha, P. (2016). Para uma história das histórias do cinema português. Aniki, 3(1), 36-45.

Cunha, I. F. (2005). A mulher brasileira na televisão portuguesa. Actas do III Sopcom, VI Lusocom e II Ibérico, v.III, 535-553.

Diogo, V. (2001). Comédias cinematográficas dos anos 30/40. Análise Social, vol. XXXVI(158-159), 301-327.

Ferraz de Matos, P. (2006). As côres do império - representações raciais do império colonial português. Estudos e Investigações, no 41. Imprensa de Ciências Sociais da Universidade de Lisboa.

Freire, I. M. (2013). Intimidade afetiva e sexual no Estado Novo. Saúde Reprodutiva, Sexualidade e Sociedade, 3, 56-61. 
Gorbman, C. (1987). Unheard Melodies:Narrative Film Music. Bloomington: Indiana University Press.

Lauretis, T. (1985). Aesthetic and feminist theory: rethinking women's cinema. New German Critique, 34 (Winter), 154-175. Stanford: Duke University Press.

Macedo, I. (2016). Os jovens e o cinema português: a (des)colonização do imaginário. Comunicação e Sociedade, 29, 271-289.

Marques, B. (2016). Um sonho cor-de-rosa - Propaganda, ideologia e (não)imagens do matrimónio nos filmes de 'comédia à portuguesa'. Cultura - Revista de História e Teoria das Ideias, 35, 289-333. https://journals.openedition.org/cultu$\mathrm{ra} / 2626$

Melo, H. P. (2014). A imigração portuguesa no Brasil: um olhar regional e de gênero nos censos populacionais de 1920-50. In Alda Mourão e Angela de Castro Gomes (coord.), A experiência da primeira república no Brasil e em Portugal, (Capítulo 18, pp. 435-454). Imprensa da Universidade de Coimbra.

Mulvey, L. (1975). Visual Pleasure and Narrative Cinema. Screen, 16(3), Autumn, 6-27.

Olchówka, O. (2016). O cinema e a legislação do estado novo: contexto e análise. ITINERARIOS, 24, 309-330. Instituto de Estudios Ibéricos e Iberoamericanos, Universidad de Varsovia.

Pereira, A. C. (2016). A Mulher-Cineasta: da arte pela arte a uma estética da diferenciação. Covilhã: LABCOM.IFP/UBI.

Ribeiro, C. (2011). O 'heróico cinema português': 1930-1950. História. Revista da FLUP - Porto. IV Série, vol. 1, 209-220.

Santos, C. A. (2005). "Mulheres Imigrantes na Imprensa Portuguesa". In Imigração e Etnicidade - vivências e trajectórias de mulheres em Portugal (pp. 51-62). Lisboa: SOS Racismo.

Santos, S. C. (2002). “A maçã de Eva: formas de conjugalidade no cinema português contemporâneo". In Actas do Colóquio Internacional Família, Género e Sexualidade nas Sociedades Contemporâneas (pp. 133-148). Lisboa: Associação Portuguesa de Sociologia. 
Representações de género e emigração no cinema português:

o caso de $O$ Pátio das Cantigas (1942)

Smiers, J. (2006). Artes sob pressão: promovendo a diversidade cultural na era da globalização. São Paulo: Escrituras.

Torgal, L. R. (coord.). (2011). O cinema sob o olhar de Salazar. Lisboa: Temas e Debates.

Torgal, L. R. (1996). Cinema e propaganda no Estado Novo: a "conversão dos descrentes. Revista de História das Ideias, 18, 277-337.

Velez de Castro, F. (2013). "Construções espácio-identitárias no cinema português. A imagem territorial do emigrante luso-brasileiro nas comédias de Lisboa". In Avanca Cinema International Conference, Avanca, pp. 876-884.

\section{FILMOGRAFIA}

Pátio das Cantigas. (1942). Real. Francisco Ribeiro, Produções António Lopes Ribeiro. Portugal. 